\title{
The author of 1 John uses the multiple references to his 'writing' as a mechanism to establish different affects and effects
}

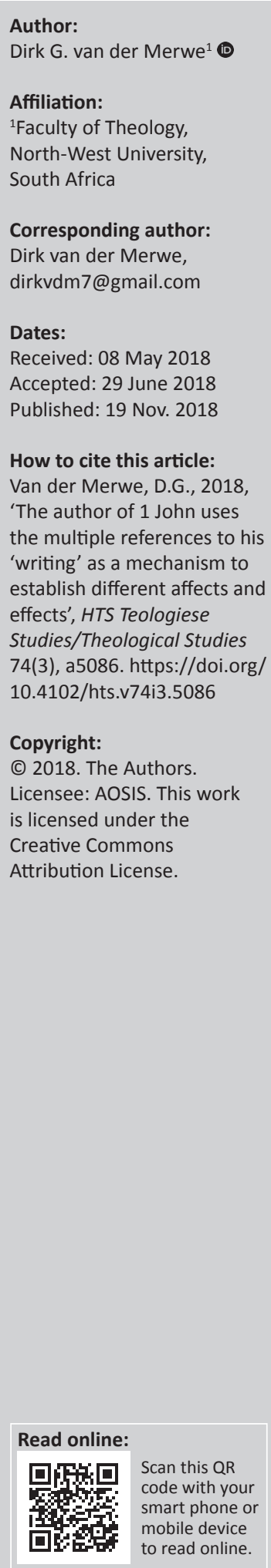

\begin{abstract}
In 1 John, the author refers several times explicitly to himself (also once in the plural, 1:4) for writing ( $\gamma \rho \alpha \dot{\varphi} \varphi \varepsilon \varepsilon v)$ certain things with the following purposes in mind, (that, iv $v$ ): 'our joy may be complete' (1:4); 'you may not $\sin ^{\prime}(2: 1)$; and 'you may know that you have eternal life' (5:13). In 2:26, he implicitly states that he has also written 'these things' ( $\tau \alpha \tilde{v} \tau \alpha)$ that (ivo) they might be victorious over the deceivers. This is the only book in the New Testament where such a high frequency of an author's reference to his own writing occurs. In 1 John

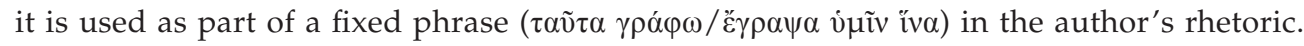
This essay focusses on the primary and secondary objectives for writing 1 John per se, and

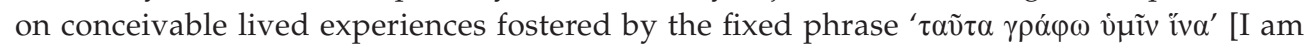
writing these things to you so that ...], as well as the mechanisms the author used to unleash these lived experiences linked with these fixed phrases. The following aspects determine the structure of this essay: the author's objectives, the expectancy of his writing, the credibility of his writing and the mechanisms the author used through which lived experiences could have been fostered to influence and convince his readers that Jesus is the Son of God.
\end{abstract}

\section{Introduction}

In the 19th century, Herman Gunkel (1888) brought a new attentiveness in the research of religious experience with his publication Die Wirkungen des heiligen Geistes nach der populären Anschauung der apostolischen Zeit und nach der Lehre des Apostels Paulus. At the end of the 20th century, Dunn (1997) also introduced new interest in religious experience and more publications followed. According to Batluck (2010:339), the research on religious experience in the New Testament over the past decades has developed into four distinctive groups. The first group ${ }^{1}$ investigates the mystical and / or revelatory experiences of early Christian texts. A second group, focusing on the historical Jesus, 'investigates historical dimensions of the religious experience described in the Gospels' ${ }^{2}$ (Batluck 2010:339). A third group relates the religious experiences of the early Christians with encounters of the Holy Spirit. ${ }^{3}$ The last group explores the magnificent capacity and realisation of religious experience fostered by texts. ${ }^{4}$ This essay relates closer to the last group, exploring the spiritualities (lived experiences) fostered by texts as part of the author's rhetoric to convince the reader to accept and believe his testimony to be true that Jesus is the Son of God and to experience the reality of the Son and the Father in their lives. ${ }^{5}$

When reading 1 John, the reader becomes aware of the author's multiple use of the verb $\gamma \rho \alpha \dot{\alpha} \varphi \varepsilon 1 v$ ('to write', 1:4; 2:1, 7, 8, 12-14 [6x], 21, 26; 5:13). ${ }^{6}$ Danker (2000:206f.) in his A Greek-English lexicon of the New Testament and other early Christian literature distinguishes the following

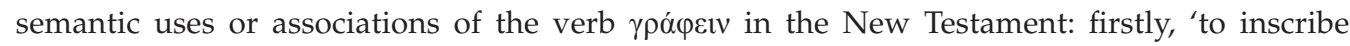
characters on a surface, write' and, secondly, 'to express thought in writing'. The latter can refer to: 'brief statements write'; 'pronouncements and solemn proceedings write down, record'; 1.See Hurtado (1988); Bockmuehi (1990); Eskola (2001); DeConick (2006); Fletcher-Louis (2008).

2.Bauckham (1978); Collins (1984); McKnight (1995); Davies (1995); Barker (1996).

3.Horn (1992); Fee (1994); Turner (1996); Hurtado (2000); Levinson (2009).

4.Johnson (1998); Hurtado (2003); Flannery (2008).

5.This will enable readers to have fellowship with all those who also believe this (1:3); their joy will become complete (1:4); it will enable them to deal with their sins $(2: 1)$. It will help them to turn their back on the deceivers $(2: 26-27)$ and finally believe that they have eternal life $(5: 13)$

6.The author nonetheless uses different semantic-related verbs for communicating the 'message' $(1: 5 ; 3: 11)$ about Jesus, each one with

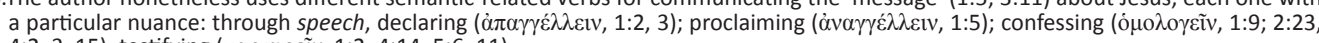
$4: 2,3,15$ ); testifying ( $\mu \alpha \rho \tau \nu \rho \varepsilon \tilde{v}, 1: 2 ; 4: 14 ; 5: 6-11)$. 
'of correspondence write (to) someone'; ' of literary composition compose, write'. For this researcher, the author's usage and application of the verb $\gamma \rho \alpha \dot{\varphi} \varphi \varepsilon v$ in 1 John falls in the category of 'pronouncements and solemn proceedings write down, record'?

This is the only book in the New Testament where such a high frequency of an author's reference to his own writing ( $\gamma \rho \alpha ́ \varphi \varepsilon v)$ occurs. In 1 John, it is used as part of a fixed phrase

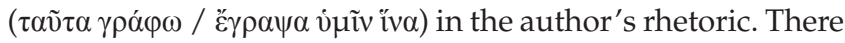
should definitely be some reason behind this. ${ }^{8} \mathrm{He}$ uses these references, 'I am writing to you', at strategic points ${ }^{9}$ in this document and where he points out various objectives for writing, using a iv $\alpha$-clause ('so that', 1:4; 2:1, 26-27; 5:13; cf. also 1:3). By doing this, it seems as if the author is using the

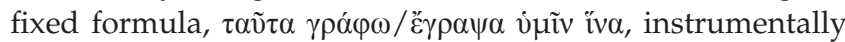
and rhetorically to gain the reader's attention to allow the reader to focus on the objectives the author wants to communicate and achieve. The repetition of him (the author) writing these things to them (the readers) can create in the reader a specific affect (spirituality) in order to achieve a definite effect (objective achieved).

This essay will focus on the objectives for writing 1 John per se, and on conceivable lived experiences fostered by the fixed


so that ...], as well as the mechanisms the author used to unleash these lived experiences fostered by the texts linked with these fixed phrases. The following aspects determine the structure of this essay: the author's objectives, the expectancy of his writing, the credibility of his writing and the mechanisms the author used to unleash the lived experiences fostered by his writing to influence and convince his readers that Jesus is the Son of God.

\section{The author points out his objectives}

To understand the author's creation of affects and effects, one must first get clarity about the objectives for writing 1 John and understand them. Different lived experiences of the divine are fostered by the multiple objectives stated for

7.Danker (2000:337) categorises the author of 1 John's use of the verb ypó $\phi \varepsilon$ iv partly incorrectly under the category 'of correspondence write (to) someone'. He is influenced by the multiple occurrences of the personal pronoun univ used in the

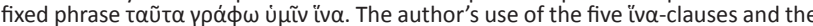
conjunctions $\dot{\alpha} \lambda \lambda \dot{\alpha}(2: 7)$, öt $(2: 12-14,21)$, and the preposition $\pi \varepsilon \rho i$ (2:26) in

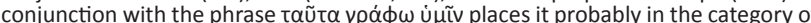
'pronouncements and solemn proceedings write down, record'.

8.Rhetoricians during the Greco-Roman era divided the genre of rhetoric into three types: forensic, deliberative and epideictic (see Aris. Rhet 1.1.1ff). Letters written in this era belong to one of these three types. Stowers (1986:51) points out that there would also be letters that would not fit into any of these three types. Klauck would also be letters that would not fit into any of these three types. Klauck (1990:205-224) classifies the rhetoric in 1 John as deliberative rhetoric. For him, the
author seeks to influence the 'decision and action' of his readers. Watson (1989:97author seeks to influence the 'decision and action' of his readers. Watson (1989:97-
110 ) differs from Klauck. For him, the rhetoric is rather epideictic. Painter (2002:87) agrees with Watson based on two reasons. Firstly, the author attempts to nurture the bonds of the community, and secondly, he tries to reaffirm the values that established the community prior to the activities of the deceivers. For this researcher, it is not a matter of 'either, or', but rather that both these rhetorical types occur in 1 John. They complement one another. For what this researcher endeavours to achieve in this essay, the rhetorical interpretation of Klauck (deliberative rhetoric) fits this reasoning better.

9.This will become clear in the individual discussions of these references. In the first reference of 'writing', it relates to imagining the life of Jesus (1:1-3). In the last reference $(5: 13)$, the same thing happens. In the middle section (Ch 2$)$, where the author refers to his 'writing' 11 times, is where a lengthy dichotomy occurs in 1 John. Where he deals with the deceivers, the author also addresses the new way

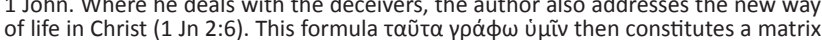
of life in Christ (1 Jn 2:6). This formula taũta
to generate 'lived experiences' in the reader. writing 1 John as well as all those aspects referred to by the author to substantiate and accomplish these objectives.

For the researcher there are two levels of objectives in 1 John: one primary objective and five secondary objectives. The primary objective for writing 1 John is to identify who Jesus is, even though there is no particular statement using a iv $\alpha$-clause to indicate this objective. The five secondary ${ }^{10}$ objectives (iv $\alpha$-clauses used) for writing 1 John are to support and complement the primary objective, namely, to believe that Jesus is the Son of God. The secondary objectives are

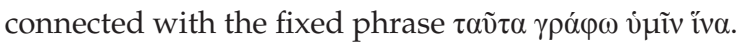

\section{Primary objective: The identity of Jesus as the Son of God}

In order to legitimise this assertion, it is necessary to point out that from the prologue, throughout the body part up to its end (second last pericope), 1 John is saturated with references to Jesus. This verifies that the author's primary objective for writing 1 John is to testify that Jesus is the Son of God.

\section{References to Jesus in the prologue (1:1-3)}

With the phrase 'O $\tilde{\eta} v \dot{\alpha} \varpi$ ' $\dot{\alpha} \chi \tilde{\eta} \varsigma$, the author describes the Word of life as 'that which was from the beginning' (1:1). He is in fact speaking principally of the Word of life who incarnated in Jesus Christ (Kruse 2000:51). ${ }^{11}$ The verb in the first relative clause ( $\mathrm{O} \tilde{\eta} \mathrm{v}, 1: 1)$ is intrinsic to the nature of the Word of life. The verbs in the subsequent four relative clauses

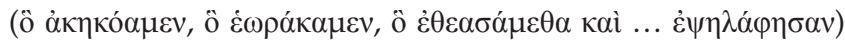
describe how others sense the Word of life (1:1), also referred to as 'eternal life' (1:2). If the first relative clause ("O $\tilde{\eta} v)$ is the precursor of the following four relative clauses, this could have signified the divinity of this person, who is from eternity. He is that person the author and those from the tradition had heard, seen, touched, proclaimed and wrote about. This reference constituted a time contrast between 'what was from the beginning' and 'what we have seen with our eyes ... and our hands have touched'. This is a contrast between eternity and this specific past event. The author and the eyewitnesses from the tradition experienced the One, who has life in himself. In fact, the author refers to him as 'eternal life' for he is from eternity and has now incarnated in time, space and history. The author refers to him as being the eternal Son of God, Jesus the Christ who came in the flesh (cf. Jn 1:14; Kruse 2000:53; Van der Merwe 2013:3).

\section{References to Jesus in the body part $(2: 1-2 ; 2: 18-3: 8 ; 4: 9,10,14)$}

In the body part of 1 John, the discussion of the references to Jesus will only focus on 'the oneness of Jesus with the Father',

10.The five objectives stated and referred to in 1 john are secondary objectives because there are no literary, content or semantic indications that the one is more important than the other. For the researcher they have the same function, namely, to refer explicitly or implicitly to the identity of Jesus.

11.This phrase constitutes an allusion to the doctrine found in the prologue of

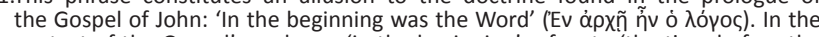
context of the Gospel's prologue 'in the beginning' refers to 'the time before the creation of the world' (Kruse 2000:51). 
references to 'the Parousia of Jesus', and finally that 'Jesus was sent by God'. ${ }^{12}$

The relation between Jesus and the Father: The pulse-beat of 1 John and equally the author's concern with eternal life is evident from the assertion in 2:22-23:

Who is the liar but the one who denies that Jesus is the Christ? This is the antichrist, the one who denies the Father and the Son..$^{23}$ No one who denies the Son has the Father; everyone who confesses the Son has the Father also. $(2: 22-23)^{13}$

This confirms the unity of the Father and the Son and the divine sonship of Jesus. Two key themes emerge from these verses: firstly, the importance to believe and to confess that Jesus is the direct object of faith (5:10), and to know that Jesus may also be misinterpreted or wrongly believed. Secondly, true faith 'in' and 'about' Jesus is inseparable from experiencing God as 'Father' and standing in a relationship with him (Lieu 1997:71).

1 John 2:22 emphasises that Jesus is 'the Christ' ( $\chi \dot{0} \chi \rho ı \tau$ tós, so also 5:1). This constitutes an affirmation of Jesus being the Messiah (is translated in Greek as $\chi \rho ı \sigma \tau o s)$ of Jewish expectation. For the author 'Jesus as the Christ' expands the Jewish understanding and meaning that he is the promised Messiah. The author's understanding of 'Christ' is no more an epithet or title. 'Christ' has now become another 'name' for the resurrected Jesus. It contributed to generating correlating terms into the vocabulary of 1 John, namely, antichristos and chrisma (Lieu 1997:71)

Equally of great importance is the confession that Jesus is the Son of God (4:15; 5:5, 10; see also 3:8) (Lieu1997:71). 1 John uses 'Son' in a more advanced sense. All references to Jesus as 'the Son', 'only Son' or 'his Son' are in close unification with 'the Father' as is evident from 2:23, 'Everyone who denies the Son, does not have the Father; the one who confesses the Son also has the Father' (see also 1:3; 4:14). Where references to God are implicit in texts $(1: 7 ; 3: 23)$, Jesus has been referred to as 'his Son'. The unity or oneness between Jesus and God or the Son and the Father can be understood as 'that for the believer experience of one carries with it experience of the other' (cf. 2:24, Lieu 1997:72).

The author uses the negative testimony of the deceivers to create a positive lived experience that Jesus is the Christ, the Son of God. If this confession abides in them, then they will experience God for they will abide in God (2:24); they will also experience eternal life (2:25).

The Parousia of Jesus: For the author the last hour (2:18) refers to the disclosure of the antichrist, referring to those who did not believe that Jesus came in the flesh (a form

12.Another aspect like Jesus as Paraclete will be discussed in one of the secondary objectives.

13.The author uses the negative testimony of the deceivers to create a positive 'lived experience' that Jesus is the Christ. If this confession, that Jesus is the Christ abides in them, then they will experience God for they will abide in God $(2: 24)$; abides in them, then they will experience God for they will abide in God $(2: 24)$;
they will experience eternal life $(2: 25)$. See my thorough discussion of the sociohistorical circumstances of the community in Van der Merwe 2007. of Docetism). This era will end when Christ is again revealed (2:28b). The author's reference to Jesus' parousia has given his declaration a special tenor. Already in the prologue he has spoken of another 'revelation' of Christ, referring to Jesus' incarnation $(1: 2 ;$ cf. $3: 5,8)$. These two different events come

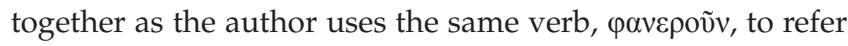
to these events (2:28; Van der Merwe 2006:1055).

The author actually uses the verb pavepoṽv as a terminous technicus. He firstly uses it to refer to the incarnation of Jesus in the past $(1: 2 ; 3: 5,8 ; 4: 9)$. He further utilises it to expose the deceivers presently in the community (2:19), and finally he uses it to explain his expectancy for the future $(2: 28 ; 3: 2)$. From the immediate literary context (2:28-3:3), it is evident that the revelation of Christ is equated with his parousia (Strecker 1996:79). By doing this, the author wants to describe both the incarnation and parousia of Jesus as a single epiphany of God. In both events, God becomes visible on earth. The first appearance of the Son of God brought redemption (4:9, $10,14)$. He also destroys the works of the devil (3:8). Through this appearance, God manifests his love (4:9). In the parousia, Jesus will be revealed again, but then as judge (Schnackenburg 1984:152), as a manifestation of God's righteousness (1:9; 2:29; also 2:1; Van der Merwe 2006:1056).

The Father sends the Son: A lived experience of God's love becomes existentially real when believing 'that God has sent his Son as the Revealer and Saviour'. For the author, Jesus embodies God's love. His triple portrayal of the mission of Jesus $(4: 9,10,14)$ explicates the phenomenology of the love of God.

To reveal himself and the divine involvement in human redemption, the Father had to send the Son into the world. In the prologue, the author refers to the physical experience of Jesus by the author himself and others. They have heard him, seen him and touched him (Hiebert 1988:203). Later in 4:9, 10 and 14 the author notifies his readers about the revelation of God's love (

God's love was revealed among us in this way: God sent his only Son into the world so that we might live through him. ${ }^{10}$ In this is love, not that we loved God but that he loved us and sent his Son to be the atoning sacrifice for our sins..${ }^{14}$ And we have seen and do testify that the Father has sent his Son as the Saviour of the world.

Each verse refers to Jesus from a different perspective: 'his only Son' (4:9); 'his Son' (4:10); 'the Son' (4:14) (cf. Van der Merwe 2005:445ff.). Jones (2010:185) states it so well by saying that the acceptance (belief) of the mission of the Son is effectively 'to accept', (and experience) the Father's love (4:9).

\section{References to Jesus at the end of 1 John $(5: 5,6,10-13)$}

Through different name references, the author characterises Jesus. The pericope starts with the personal name, Jesus, to let the reader know about whom he (the author) is writing. In the pericope, he refers to him once as Jesus Christ (5:6), thrice as Son of God $(5: 5,10,12)$, thrice as his Son $(5: 9,10,11)$, the 
Son once (5:12), and in 5:11-12 he is identified with life. Instead of using personal pronouns, the author uses this variety of titles to emphasise Jesus' identity and his relationship and affinity with God. He is the life given by God, which exposes God's testimony.

In 5:11 and 12, four references to 'life' occur. In 5:11, life is defined as 'life is in the Son' and constitutes the content of the protasis of verse 12, 'Whoever has the Son has life'. In $5: 12$, the antithetical parallel clauses state the relation between having the Son and having life. The possession of the Son comprises the possession of life in its fullness. To believe means possessing Christ himself. It also means to possess (and experience) the life the Father grants to those who believe in Jesus as the Son of God as Lord and Saviour. What matters here is a person's relationship with the Son. The verb 'has' ( $\varepsilon \chi \varepsilon 1)$ is used in the present participle active mode. This life is already a present possession and experience (Akin 2001:202). A further explanation of this life occurs in 5:10.

After giving clarity again about who Jesus is, the author then personalises the references to Jesus by putting the reader before a choice in the last verse, 'Whoever has the Son has life; whoever does not have the Son of God does not have life' (5:12). This relates to $2: 23$, 'No one who denies the Son has the Father; everyone who confesses the Son has the Father also'.

\section{Secondary objectives}

\section{Analysis of configurations}


The following is a brief analysis to point out some configurations in the author's distribution and application of this phrase in 1 John (see Figure 1).

From this analysis, the following configurations are evident. The author had certain purposes in mind when he was writing. The five secondary objectives are evident from the iv $\alpha$-clauses $(1: 3,4 ; 2: 1,26-27 ; 5: 13)$. In 1:3, he substitutes the verb 'writing'

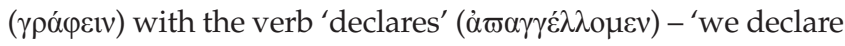
to you what we have seen and heard so that you also may have fellowship with us'. The other objectives connected to his 'writing' are, 'so that our joy may be complete' (1:4); 'so that you may not $\sin ^{\prime}(2: 1)$. In 2:26, he implicitly states that he has written these things (regarding the deceivers) '... so that you do not need anyone to teach you' (2:27), and in 5:13, 'so that you may know that you have eternal life'.

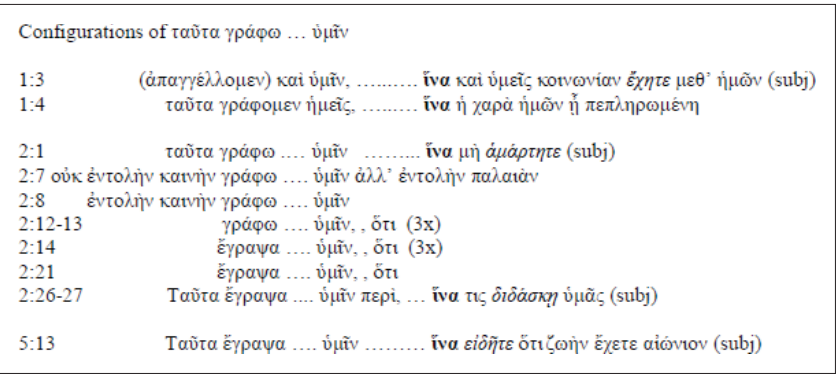

FIGURE 1: The configuration of the author's references to his writing.
The author uses the relative pronoun $\tau \alpha \tilde{\tau} \tau \alpha$ [these things] as a compound word four times in the five objectives. He uses

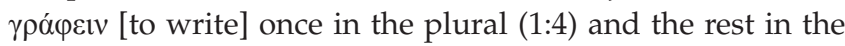
singular. In four of the iv $\alpha$-clauses [purpose], the verb occurs in the subjunctive mood. This fixed repetition in different contexts is to get the reader's attention, to emphasise the primary purpose and to create different 'lived experiences' of the Father and the Son.

\section{The secondary objectives explained}

'We declare to you what we have seen and heard so that you also may have fellowship with us' (1:3): The author perceives himself 'declaring' an authoritative message to his readers ${ }^{14}$ and announces that the immediate purpose of this declaration is to experience fellowship (with both others and the divine, 1:3), fostered by a consecutive objective that is joy (1:4; cf. Stott 2009[1964]:63). According to Smalley (1989:11), the author wants his congregation, who, at the time of writing, are divided in their perception of Jesus, to continuously ${ }^{15}$ experience 'fellowship' with him about what he 'is writing'. Then, together, they must corporately enjoy fellowship (a lived experience) 'with the Father and with his Son Jesus Christ' (1:3; cf. 1:6-7) through their faith and conduct.


in' or 'participation with' (Thomas 2006:70). ${ }^{16}$ The practical and experiential dimension of the author's theology is apparent here. Knowledge of Jesus leads to the experience of Jesus and consequently leads to action (cf. 2:3, know, sure, obey). The effect of 'hearing', 'seeing' and 'touching' Jesus is

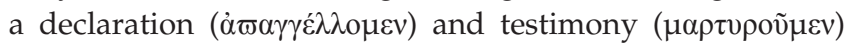
about him (1:2-3), and an invitation to have fellowship in him (Smalley 1989:11-12) and with him. The protasis of 1:3 refers to the act of fellowship among these believers: a communion on the human level, deriving from the communal indwelling in Christ.

In the apodosis, the nature of Christian fellowship is described with reference to its divine derivation. This concerns 'a fellowship which we have with the Father' (Smalley 1989:12). Christian fellowship is in effect a sharing 'with the Father, and with his Son Jesus Christ'. The Son makes God known as Father. Hence, knowledge of God's involvement in the incarnate life of Christ (cf. Jn 17:3) constitutes both ideas of human and divine 'fellowship' (cf. Law 1909:371). The reference to Jesus as 'Son' definitely influenced the author's use of 'Father' to designate God

14. This is vident in the.............



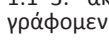

$15 . \varepsilon ̋ \chi \eta \tau$, , (literally, [you may have]) is used in the present tense.

16. Danker (2002:552) defines it as 'close association involving mutual interests and sharing, association, communion, fellowship, close relationship'. The analytica lexicon of Friberg, Friberg and Miller $(2000 \cdot 233)$ describes it as 'a relationship lexicon of Friberg, Friberg and Miller (2000:233) describes it as 'a relationship characterized by sharing in common fellowship, participation'. The semantic dictionary of Louw and Nida (1996:I, 445) defines it as 'an association involving close mutual relations and involvement - "close association, fellowship"'. From cese three dictionaries, it seems that the noun 'fellowship" is defined as event (experiential) word to denote a 'close relationship, participation, close
mutual relations and involvement' to complement and substantiate Thomas' interpretation. 
(cf. 1:2; also 2:22-24). The combination of 'Father-Son' reflects the distinctive relationship between God and Jesus ${ }^{17}$ (Smalley 1989:13; cf. also Marshall 1978:227; Thomas 2006:70).

'We are writing these things so that our joy may be complete' (1:4): In 1 John 1:3, the author refers that the purpose of their declaration ( $\dot{\alpha} \varpi \alpha \gamma \gamma \varepsilon \dot{\varepsilon} \lambda \mathrm{o} \rho \varepsilon v)$ is to encourage an intense shared fellowship. In 1:4, a second objective occurs: 'in order that

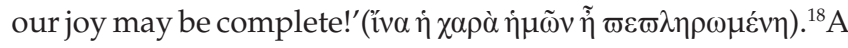
parallel structure occurs between 1:3a and 1:4. The purpose clauses introduced by the conjunction iv ('so that') in both indicates that the proclaimed message (1:3a) and the written message (1:4) are exactly the same (Stott 2009[1964]:65). ${ }^{19}$ The proclamation of both the author and the apostolic witnesses (what we have heard, seen and touched) to the readers in the past and now is the identical message $(\tau \alpha \tilde{v} \tau \alpha)^{20}$ that he is declaring in the process of him writing ${ }^{21} 1$ John. When the fellowship realises, then everyone involved in this fellowship will also share in this joy (Akin 2001:59-60). This implies that the anticipated result of both the spoken ( $\dot{\alpha} \varpi \alpha \gamma \gamma \varepsilon \dot{\varepsilon} \lambda \mathrm{o \mu} \varepsilon v, 1: 3 \mathrm{a})$ and written ( $\gamma \rho \alpha \dot{\varphi} \varphi \varepsilon ı v, 1: 4)$ message ( $\dot{\eta} \dot{\alpha} \gamma \gamma \varepsilon \lambda i \alpha, 1: 5)$ about Jesus, to be the Son of God, which constitutes the foundation of the author's composition, is 'joy'. This joy comes from fellowship with the author and vice versa and should depict the fellowship of the readers (Ac 13:52; cf. Phlp 2:2) (Akin 2001:58-59; Smalley 1989:14-15).

The verb $\varpi \varepsilon \varpi \lambda \eta \rho \omega \mu \varepsilon ́ v \eta$ in the apodosis of 1:4 includes the notion of 'to bring to completion that which was already begun, complete, finish' (Danker 2000:828). The concept 'completion of joy' occurs frequently in the Gospel (cf. Jn 3:29; 4:36; 15:11; 16:24; 17:13; see also 2 Jn 12). Here it denotes the perception of 'fellowship' with either God or with fellow believers. This kind of fellowship and the joy that will result from it will only be completed 'when mutual fellowship in Christ among the members of the circle is restored' (Smalley 1989:15).

17.In the Gospel of John, Jesus is identified as the Son of God or the Son of the Fathe $(1: 18,34,49 ; 3: 16-18,35 ; 5: 25 ; 10: 36 ; 11: 4,27 ; 19: 7 ; 20: 31)$. The oneness between the Son and Father is also apparent from 4:34; 5:19-21, 23-24, 36, 30; 6:38-39, 44; 7:16, 18, 28; 14:13; 17:1 (cf. Thomas 2006:70).

18.According to Smalley (1989:14), the author regularly reflects the teaching of the Gospel of John. This phrase echoes Jesus' expression in John 15:11 ('I have told you this so that my joy may be in you and that your joy may be complete', using $\dot{\eta} \chi \alpha \rho \alpha$ $\dot{u} \mu \tilde{\omega} v \pi \lambda \eta \rho \omega \theta \tilde{n})$. Also in John 16:24, Jesus said to his disciples, 'Ask and you will

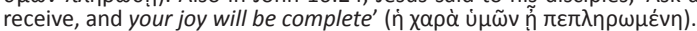

19.This interpretation is strengthened by ũ $\mu$ vv ([to you], present in 1:3a but implied in 1:4. The same audience is in view in both the proclamation and the writing.

20.According to Wallace (1997:333), the singular demonstrative pronoun is used regularly to refer to either an antecedent or a post-cedent, while 'the plural is almost exclusively shut up to retrospective uses'. For Wallace 3 John 4 is a lone almost exclusively shut up to retrospective uses'. For Wallace 3 John 4 is a lone



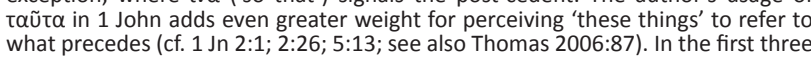
verses, the author reminds his readers about the origins of the Gospel (Kruse

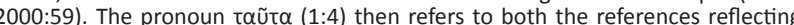
Jesus' incarnation (1:1-3) as well as the author's and reader's fellowship with the Father and his Son - to imagine and experience it. All this would cause them to experience complete joy.

21.The author's repetitive reference to his 'writing' in the rest of 1 John ( $1 \mathrm{Jn} 2: 1,7,8$, $12,13,14,21,26 ; 5: 13)$ offers a clear indication that he was in the process of writing. If $20 \tilde{0}, \alpha$; writing. If tavta refers to the message of the entire epistle, it disturbs the 'istinction between referent' (Akin 2001:60). Grammatically considered, the pronoun tavta then refers strictly speaking to the testimonies of the eyewitnesses about the Son of God's incarnation as referred to in $1: 1-3$, even though the content of this testimony is presented in the rest of $1 \mathrm{John}$ (Akin 2001:60).
'I am writing these things to you so that you may not sin' (2:1): The third objective (iv $\alpha$ ) connected with the author's reference to his writing occurs in 2:1. This objective for writing is actually an exhortation that the readers 'may not $\sin ^{\prime}$ anymore. The things ( $\left.\tau \alpha \tilde{v} \tau \alpha\right)$ the author refers to in this reference to his writing are about the situations projected for either condemnation or commendation in 1:6-10 (Kruse 2000:17). After warning his readers against denying sin (and thus denying God and Jesus) like the deceivers, the author adds the thought about dealing with sin in the proper way (i.e. through Jesus) for himself and his readers, which consist of two aspects of Jesus' work:

1. Jesus is the Paraclete (2:1).

To encourage the believer, the author approaches the obstacle of sin positively: 'if anyone does sin, we have an advocate

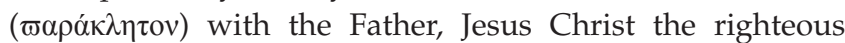

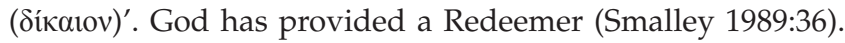
Again, Jesus is the focus point. He is the paraclete, the


$\varpi \alpha \tau \varepsilon \rho \alpha)$. In his position as Son and function of intercessor,

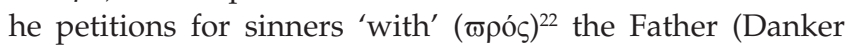
2000:875). The description of Jesus as paraclete emphasises his action when a believer commits sin. It also reveals Jesus' role in facilitating fellowship between the Father and believers as well as bringing additional meaning to Jesus' work of cleansing earlier (1:7, Thomas 2006:89). Jesus Christ is here also called díkalos [righteous]. This reference to Jesus, 'being righteous', emphasises his ability to intercede on behalf of sinners. He shares in the natures of both God and human. Therefore, because of this, he is the one who has 'fulfilled all righteousness' (Mt 3:15; Smalley 1989:37):

1. Jesus is the atoning sacrifice (2:2).

Moving to address the work of Jesus Christ, the author adds another related thought using the conjunction particle кai [and] in 2:2. He links Jesus' propitiation as the basis for the forgiveness of sin and the effect of abiding, not only for them but also for all alike (cf. Akin 2001:77). The author has already indicated in 1:7 that those who have fellowship with God are those who live in the eternal life God has revealed in Jesus.

The primary denotation of i $\lambda \alpha \sigma \mu$ ó $\varsigma$ in this verse is to emphasise two things: the atoning death of Jesus is the foundation on which both cleansing and forgiveness rest. It constitutes the foundation of his intercession with the Father.

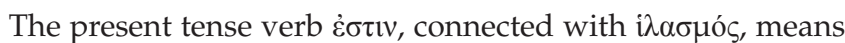
that the atoning death of Jesus has a continuing significance for those believing in him (Thomas 2006:90). For Painter (2002:158), this sequence of presentation of ideas reflects how the author perceives God the Father dealing with human sin through the sending of the Son.

'I write these things to you concerning those who would deceive you ... so you do not need anyone to teach you' (2:26-27): The author's fourth secondary objective connected with his reference to his 'writing' occurs in 2:26-27. 22.Danker (2000:875): 'be (in company) with someone'. 
In 2:18-28, he heftily opposes the deceivers. The pronoun $\tau \alpha \tilde{\tau} \tau \alpha(2: 26)$ refers in particular back (2:18-25) and forward to $2: 27-28$. The primary reference here is that the author opposes the deceivers who wanted to lead the readers astray. They probably attempted to influence the readers to adopt their teaching. If this is true, there is a reminder that the readers already had an anointing from God, so (iv $\alpha$ ) they 'do not need anyone to teach' them $(2: 27){ }^{23}$

Two dominant themes, stated in 2:20, 24, are combined in this one statement. These two themes, 'anointing from God' (2:20) and 'that heard from the beginning' (2:24), are not juxtaposing but complementing one another (Thomas 2006:138). This is evident from 2:23-24:

No one who denies the Son has the Father; everyone who confesses the Son has the Father also. ${ }^{24}$ Let what you heard from the beginning abide in you. If what you heard from the beginning abides in you, then you will abide in the Son and in the Father.

Again, in this objective as in the three previous objectives $(1: 3,4 ; 2: 1),{ }^{24}$ the author stimulates the readers' imagination and lived experiences with the pronoun $\tau \alpha \tilde{v} \tau \alpha$, to be filled by the reader. The pronoun 'all things' (2:26) needs to be understood contextually. The acute subject under discussion is the denial that Jesus is the Christ, the Son of God who became flesh. Nothing they need to know about Jesus' identity has to be learnt from the deceivers. They have already received everything they need to know about Jesus and his relation with God through their anointing (Kruse 2000:108).

'I write these things to you who believe in the name of the Son of God so that you may know that you have eternal life' (5:13) $^{25}$ : The author's fifth secondary objective, connected with his reference to his 'writing', occurs in 5:13. The denials of the deceivers that Jesus is the Christ, the Son of God, probably upset the adherents of the author. This objective for writing 1 John was to reassure his adherents about Jesus' identity. This was to counteract the pseudonymity of the deceivers. The author was convinced that his readers had received eternal life. In fact, they (his readers) know God and not the deceivers (Kruse 2000:188). They manifested the characteristics of those who have and experienced eternal life: they live in the light (1:7); they persevere in the teaching first proclaimed by the eyewitnesses; they were obedient to the commandments (2:3) of the Lord; and they loved the children of God (2:10, cf. Kruse 2000:189).

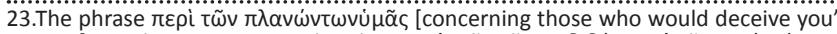

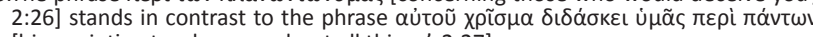
[his anointing teaches you about all things', 2:27].

24.1:3 (ö ह்

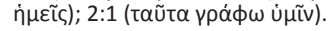

25.1 John 5:13 can be interpreted as a transitional verse. According to Smalley (1989:289), in retrospect, this verse looks back to the subject matter of 5:5-12, and in prospect postulates a summary conclusion to 1 John to introduce the closing remarks of 5:14-21. Because of this, some commentators (e.g. Schnackenburg
1984:272-273; Westcott 1982:188) as well as some versions (e.g. rsv; niv) make a break after 5:12. Conversely, the contents of 5:13, regarding 'believing in the Son of God' and 'possessing eternal life', rather imply that this verse belongs to the preceding passage (5:5-12), while 5:14 introduces the new topic of prayer. The inclusion of verses 5 and 13 at the opening and closing of the present section verifies this selection. In these verses, repeated allusions to faith in the Son of God occur (see Bultmann 1973:83).
Before this climactic statement of the author, he incorporates four more witnesses in order to emphasise that Jesus is the Son of God:

There are three that testify: ${ }^{8}$ the Spirit and the water and the blood, and these three agree. ${ }^{9}$ If we receive human testimony, the testimony of God is greater; for this is the testimony of God that he has testified to his Son. ${ }^{10}$ Those who believe in the Son of God have the testimony in their hearts. Those who do not believe in God have made him a liar by not believing in the testimony that God has given concerning his Son. (1 John 5:8-10)

\section{Conclusion}

From this brief discussion, it became evident that in all these

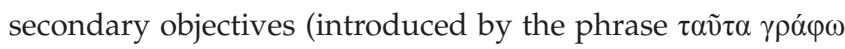
v $\mu \mathrm{i} v$ iv $\alpha$ ), the author complements the primary objective from different perspectives that Jesus is the Christ the Son of God (and that he and God are one). 1 John 1:3 refers to the fellowship with both Father and Son. The joy referred to in 1:4 relates to Jesus' eternal existence, his incarnation, to be the Son of God and the readers' fellowship with the divine. The secondary objective in 2:1, referring to 'sin no more', relates to the Father's forgiveness of sin in the name of Jesus and Jesus' intervention for the sinner by the Father. In 2:26-27, the author uses his contest with the deceivers to emphasise the unity between the Father and the Son. In 5:13, he incorporates the testimonies of the water, blood, Spirit and God that Jesus is the Son of God to strengthen his primary testimony about the identity of Jesus.

In four of the secondary objectives, the author uses the pronoun $\tau \alpha \tilde{\tau} \tau \alpha(1: 4 ; 2: 1 ; 26-27 ; 5: 13)$ for the readers to fill it with their imaginations in order to obtain lived experiences of the divine when they give meaning and content (about the identity of Jesus) to it. In the first secondary objective, he also



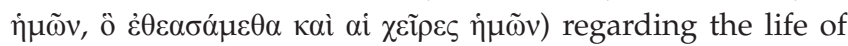
Jesus to which the readers had to give content and meaning.

\section{A writing with expectancy}

From the five secondary objectives, it is clear that the author is writing with expectancy that the readers will adhere to these objectives. In four of the objectives, the author uses the subjunctive mood: twice the present active subjunctive (ivo

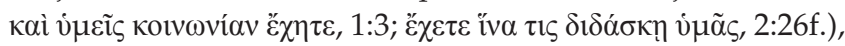

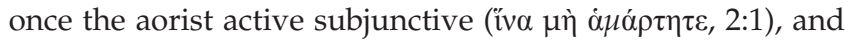

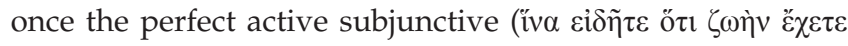
aíviov, 5:13). In 1:4, the author uses the perfect passive

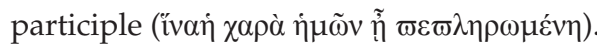

\section{According to Porter et al. (2010):}

Nonindicative moods (subjunctive, optative, and imperative) indicate the 'projection' of a verbal event according to the mind or view of the speaker or writer. In other words, by using a nonindicative mood, the author creates a 'possible' world or state of affairs. The subjunctive mood is used to express a projected realm that may at some time exist and may even now exist, but is held up for consideration simply as a projection of 
the speaker's or writer's mind. For this reason, the subjunctive is often said to express possible events. Words like 'may', 'might', or 'should' are often suitable for translating the subjunctive mood, but at times this will not be appropriate. In a translation, it is possible to capture the idea of a 'projected' or 'possible' action. In some cases, the future is appropriate... (p. 155;26 also cf. Wallace 2009:206)

This then implies that the subjunctive mood refers to the action or the event as something wanted or expected. The author expects from his readers to adhere to these secondary objectives. If they do, their faith and testimony also will designate that Jesus is the Son of God.

\section{The author establishes the credibility of his writing}

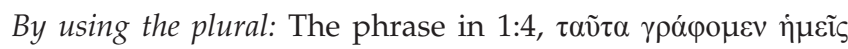
[We are writing these things], with the subject referred to in both the verb and the pronoun, is deliberately emphatic in order to attract the readers' attention. By using the plural pronoun $\eta \mu \varepsilon i{ }^{\prime}[w e],{ }^{27}$ the author refers to his solidarity with representatives of the tradition (cf. Smalley 1989:14; also Akin 2001:60) in the early church. ${ }^{28}$ The author represents those who are indebted for their faith to the apostolic kerygma (cf. Kistemaker \& Hendriksen 2001:29). This connects him with the truth of the apostolic tradition and legitimises him to


Smalley 1989:14). Insinuations of standing in line with the tradition confirm the truth of the content of this writing. This creates in the reader a lived awareness that the author's teaching is fostered by the teachings of the early authors and that it is true. He could probably also have had in mind the author(s) of the Gospel of John. The author acts here as a representative of many eyewitnesses (Haas, De Jonge \& Swellengrebel 2001:18).

By incorporating more witnesses: In chapter 5, we find the

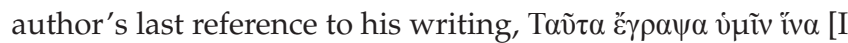
wrote these things to you so that]. The pericope prior to this purpose statement by the author (5:6-12) is closely linked to this verse $(5: 13)$ with the use of the pronoun $\tau \alpha \tilde{v} \tau \alpha$ [these things]. Hence, the pronoun $\tau \alpha \tilde{v} \tau \alpha$ in 5:13 refers similarly as in the cases of 1:4, 2:1 and 2:26 primarily to the immediate preceding pericope (5:5-12) and secondarily to everything he


a ccomplishment'. 'In many cases, purpose and result cannot be clearly differentiated, hence iv $\alpha$ is used for the result which follows according to the pifferentiated, hence iv $\alpha$ is used for the result
purpose of the subj[ect] or of God' (2009:206).

27.This is further strengthened by also using the personal pronoun plural $\dot{\eta} \mu \tilde{\omega} v$ [we] as well as the following verbs in the first person plural: ö óknкó $\alpha \mu \varepsilon v$, ö ह் $\omega \rho \alpha \dot{\alpha} \alpha \mu \varepsilon v$

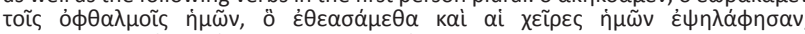



28.The author acts here as a representative of many eyewitnesses (Haas et al. 1994:18). The context in which the word 'tradition' has been used probably refers back to the Johannine 'tradition'. 1 John is deeply embedded in this tradition. See commentaries on the explanation of the text of 1 John.

29.Scholars are uncertain what the pronoun taũ $\alpha$ (literally [these things]) relates to.

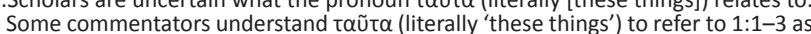
a general reference to the spoken or written proclamation of the Christian gospel (Smalley 1989:14). According to Haas et al. (2001:28), taũta refers to the entire (Smalley 1989:14). According to Haas et al. (2001:28), taũta refers to the entire
content of 1 John. Owing to this uncertainty, it was probably an open agenda for the readers to interpret it differently in indifferent contexts. has written up to this point..$^{30} \mathrm{~A}$ further motivation is that the high frequency of references to testimonies relates to the multiple references of the author's testimonies and his writing of 'these things' ( $\tau \alpha \tilde{v} \tau \alpha)$.

The author, already encouraged by the apostolic tradition, strengthens his testimony about Jesus even further by complementing his testimony with more testimonies concerning the identity of Jesus. ${ }^{31}$ The text can be divided into two subsections: 5:5-8 $8^{32}$ and 5:9-12 (cf. Thomas 2004:256). In 5:6-8, the author only refers to the three that testify, the Spirit, ${ }^{33}$ water and blood, as a preamble for his discussion of God's testimony in 5:9-12. In 5:9, the author states that 'the testimony ( $\dot{\eta} \mu \alpha \rho \tau$ pí $\left.^{\alpha}\right)$ of God is greater'. It implies a comparison (greater) with human testimony. It is greater than human testimony and could have created a curiosity in the reader. Why is it greater? It is only in verse 11, the last time that he refers to God's testimony (again using the noun, $\mu \alpha \rho \tau$ pí $\alpha$ ), that he gives clarity to satisfy the reader's expectancy: 'And this is the testimony: God gave us eternal life, and this life is in his Son'. Now, a double testimony takes place on two different levels. The author testifies about God's testimony.

The author then strengthens his own and these testimonies by incorporating divine testimony in the latter part of the pericope that Jesus is the Son of God. This reasoning is taken by the author to another and higher level by making the testimony of God personal, linking it 'to believe' (5:10).

\section{Mechanisms used by the author to create affects and effects from the texts}

For the author to influence his readers rhetorically into believing his testimony and to adhere to his exhortations (effects) spelt out in his objectives, through his preaching and writing, he attempted to evoke lived experiences (affects) in his readers. They have to experience the Son ${ }^{34}$ and the Father. Those who heard or read the author's proclamation could have experienced (see, hear) the divine in their minds, thoughts and feelings. Luke wrote in Acts 2:37, 'Now when they heard this, they were cut to the heart ...'. This implies 30 .See footnotes 20,21 and 29 .

31.In the Gospel of John, multiple witnesses to Christ are referred to and extend over many possible verifications of divine things. There is: '(1) the witness of the Father: (2) the witness of Christ Himself; (3) the witness of works; (4) the witness of Scripture; (5) the witness of the Forerunner; (6) the witness of disciples; and the Scripture; (5) the witness of the Forerunner; (6) the witness of discipl
Baptist, (7) the witness of the Spirit' (Westcott 2004[1908]:92-98).

32. Some commentators see 5:5 as the beginning of a new section (Bultmann 1973:79; Marshall 1978:230; Schnackenburg 1984:255; Smalley 1989:272) following the Greek text. Others who take 5:5 with the previous section, as the theme of overcoming is continued, are Bruce (1970:116), Westcott (1982[1886]:176) Thompson (1992:129), Akin (2001:193), Painter (2002:312), Thomas (2006:214), and Stott (2009[1964]:174). This article prefers to take 5:5 with the following pericope $(5: 6-12)$ because it slots in with the rhetoric of the pericope and the rest of the content of 5:6-12.

33. References to the Spirit occur eight times in 1 John $(3: 24 ; 4: 2,13 ; 5: 6[$ bis] $7,19,20)$, of which three occurrences are related to testimony about Jesus in $5: 6,7$. In the farewell discourse of the Gospel of John, references also occur where the special agency of the truthful Paraclete is described as testifying to Jesus (15:26; 16:13-14; cf. $14: 26 ; 16: 7-11)$.

34.The Word of life or Eternal life. 
that the lives of those who heard Peter's preaching were transformed.

Waaijman (2002:742) contends that readers shape the portrayal 'of sacred texts in their imagination'. This is an agency for them for effective participation in the texts. Such participation denotes that sincere and contemplative reading of biblical texts can produce various lived experiences of both the divine and the text. These 'lived experiences' are dependent on the text content communicated regarding the divine as well as who the reader is. The rest of this essay will focus on identifying some mechanisms used by the author to create certain 'lived experiences' of the divine in the audience which relate to and are closely connected with the fixed

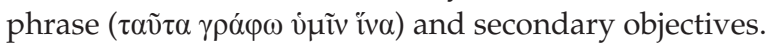

\section{The dynamic interaction between the text and the reader \\ On a personal level}

In chapter 2, the first reference (2:1, see also 2:12) to $\gamma \rho \alpha \dot{\varphi} \varphi \varepsilon v$,

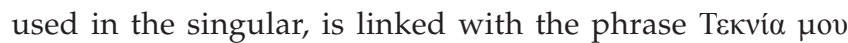
[my little children] ${ }^{35}$ to make his writing more personal and intimate. The personal appeal of the author is striking. He addresses his audience as $\tau \varepsilon \kappa v i ́ \alpha$ Hov [my little children', referring to 'my dear friends' or 'my dear ones'] (Louw \& Nida 1996:I, 110), which occurs mostly in the New

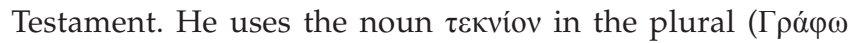

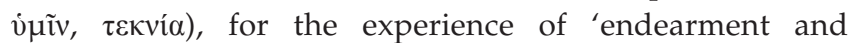
intimacy' (therefore translated as, 'my dear/little children', cf. $2: 12,28 ; 3: 7,18 ; 4: 4 ; 5: 21)$.

In 2:14, 18 (also Jn 21:5), the readers are simply referred to as

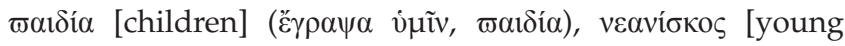

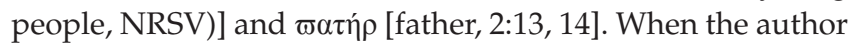
describes the believers with these terms, it is to distinguish between them and to create intimacy and imaginations about family life (cf. Smalley 1989:34). ${ }^{36}$



It is only in the first reference to his writing in the prologue (1:4) where the author uses the plural. The repeated subject in

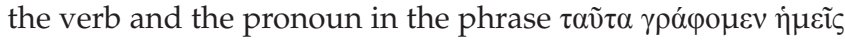
is deliberately emphatic: 'we (the author, in solidarity with all the representatives of the [Johannine?] tradition) are writing these things' (cf. Smalley 1989:14). In contrast to this solemn, joint proclamation of the apostolic message, the subsequent uses of $\gamma \rho \alpha \dot{\varphi} \varphi \varepsilon v$ are always in the context of an intimate and personal address (Smalley 1989:14). In the rest of 1 John $(2: 1,7,8,12,13[2 x), 14(3 x], 21,26 ; 5: 13)$, the verb

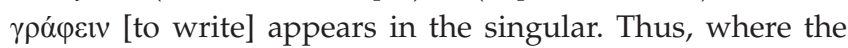
reference to $\gamma \rho \alpha \dot{\varphi} \varphi \varepsilon v$ in the plural (1:4) creates solidarity with the apostolic witnesses, the singular usage of it ( $\gamma \rho \alpha \dot{\varphi} \varphi \omega /$ है $\gamma \rho \alpha \psi \alpha)$ in chapters 2 and 5 could have created intimate and personal lived experiences of the content attached to this writing. The use of the personal pronoun viñv in the dative, 35.See also 1 John $2: 12,28 ; 3: 7,18 ; 4: 4 ; 5: 21 ; 3$ John 4 ; John $13: 33$ and Galatians 4:19. 36.These distinctions have nothing to do with different levels of spiritual growth.
'I am writing these things to you', strengthens the interaction between the author and the reader.

\section{Figures of style used by the author}

Dialectic language: In both 5:10 and 12 (also 2:23), ${ }^{37}$ the positive statements in the protasis are followed by negative statements in the apodosis of the parallelisms. These two comparisons are absolutely radical with regard to 'faith in' and 'possession of' the Son of God. There is no midway. Those who do not believe (5:10), who do not have the Son (5:12), do not have the testimony of God and do not have eternal life. These two dialectic statements, constituted by antithetical parallelisms, also could have created tension in the reader to necessitate self-investigation, resulting in making a choice. The tension is intensified by the author's use of the two nouns $\dot{\alpha} \lambda \dot{\eta} \theta \varepsilon 1 \alpha$ [truth] and $\psi \varepsilon v \dot{\sigma \tau \eta \eta}$ [liar] in the phrases 'the Spirit is the truth' and 'those who do not believe in God have made him a liar'. This discrepancy with regard to the divine emphasises the truth and reality of divine witness and involvement.

Participle constructions in 5:5-12: In this short pericope, seven participle constructions ${ }^{38}$ occur with six applicable to

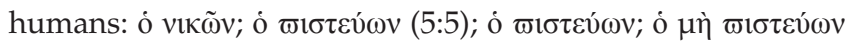

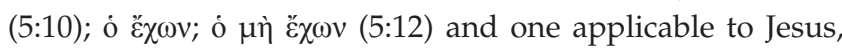

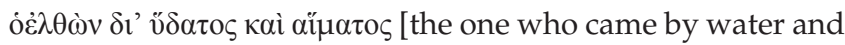
blood, 5:6]. Those applicable to humans are used by the author in each of the verses antithetically in pairs to create a stronger effect. All six are in the present, active, participle, masculine, singular and nominative. The use of the participles in the present active mood in this context is to emphasise reality and continuity. These believers have to experience everyday victory over the world (5:5), their faith in Jesus as the Son of God (5:10) and Jesus living in them (5:12).

Repetition creates excitement: The prologue probably radiates the excitement ${ }^{39}$ of the author who wants his readers to share in it. For Van der Merwe (2013:4), this excitement is apparent from the literary text, by way of repetition. Three times the


Jesus Christ the Son of God (1:3), three times that they have


only once that they have touched him with their hands ( $\alpha i$ $\chi \varepsilon \bar{\rho} \rho \varepsilon \varsigma \dot{\eta} \mu \tilde{\omega} \nu \dot{\varepsilon} \psi \eta \lambda \dot{\alpha} \varphi \eta \sigma \alpha v, 1: 1)$. He uses the forensic verb

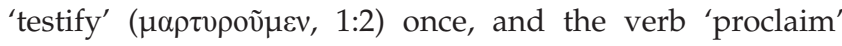
( $\left.\dot{\alpha} \varpi \alpha \gamma \varepsilon \dot{\varepsilon} \lambda \lambda_{0 \mu \varepsilon v}, 1: 2,3,5\right)$ three times. This excitement

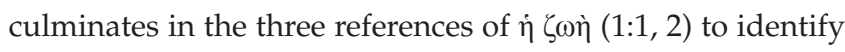

37.1 John 5:10-12: 'Those who believe in the Son of God have the testimony in their hearts. Those who do not believe in God have made him a liar by not believing in the testimony that God has given concerning his Son. ${ }^{11}$ And this is the testimony: God gave us eternal life, and this life is in his Son. ${ }^{12}$ Whoever has the Son has life; whoever does not have the Son of God does not have life'. 1 John 2:23, 'No one who denies the Son has the Father; everyone who confesses the Son has the Father also'. Dialectic language occurs throughout $1 \mathrm{John}$. Here the researcher will only focus on the two texts above.

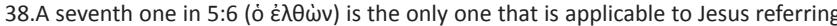
to him as the 'one who came' through water and blood.

39.It should not be taken for granted that the emotions and 'ived experiences' which modern day believers/readers form from biblical texts were the emotions evoked in writers and readers in the first century Mediterranean world. This is only a probable projection of a reader's emotion to the author of $1 \mathrm{John}$ 


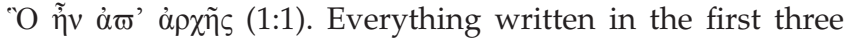
verses relates to $\dot{\eta} \zeta \omega \grave{\eta}$ (Van der Merwe 2013:4).

Repetition also creates vividness where the present ( $\gamma \rho \alpha \dot{\varphi} \varphi \omega)$ and


section of the second pericope in chapter 2 consists of six sentences (2:12-14), of which each contains the verb $\gamma \rho \alpha \dot{\varphi} \varphi \varepsilon ı$. These sentences (12-14) are located between preliminary dialectic references of loving a brother or sister opposite $(2: 10)$ to hating a brother or sister $(2: 9,11)$ and followed by the dialectic reference to love the world (2:15) opposite to do the will of God (2:17). The sentences (12-14) are grouped into two groups of three statements. In the first group the verb

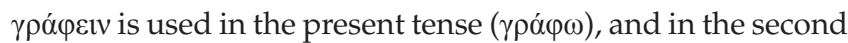
group the aorist $(\ddot{\varepsilon} \gamma \rho \alpha \psi \alpha)$ is used (Watson 1989:97). The reason for using two groups of parallel statements is for emphasis and to attract the reader's attention intensely. ${ }^{40}$ Watson (1989:102) points out that 'repetition creates vividness, especially when using the past tense instead of the present'. A comparison of both groups proves that there is virtually no difference in the aspects referred to. The author wants to attract their attention to let them focus on and experience again what happened to them. ${ }^{41}$ The whole section serves to amplify the positive and uplifting evaluation of the community by the author (cf. Watson 1989:103) before starting his vehement criticism of the opponents, starting from 2:18.

The shift from present to past tense lends variety and dynamism. The reader experienced the intensity constituted by the repetition in the past tense. This contributes to the author's emphasis upon the reality of the qualities that the readers already possess, which he advocates in his earlier arguments (1.5-2.11; Watson 1989:105). In all these affirming statements the perfect tense is used, implying that actions conducted in the past still continue in the present (Painter 2002:186). They were probably in need to realise and to experience that their sins are forgiven (see 2:1). Therefore, the author uses the perfect passive, 'They have been forgiven, in fact they are forgiven' (2002:186).

\section{The imaginative composition of images}

Iser points out that in any reading process the readers' imagination composes images related to what they are reading. The reader subjectively and selectively composes '... the images out of the multifarious aspects of the text as well

40.According to Watson (1989:107), this entire passage is a conduplicatio. It serves to compliment the readers, to emphasise certain topics and to prepare them for his attack on the deceivers. At this point of reading, the believers felt satisfied about what the author wrote about them regarding their relationship with God. He raised critical aspects to prepare them for what he will communicate in the rest of chapte 2 with regard to the deceivers and the rest of 1 John with regard to their way of living. For Nordquist (2017), 'Conduplicatio is a rhetorical term for the repetition of one or more words in successive clauses'. It can also be referred to as 'reduplication'. According to Cicero (Rhet. Her. 4.28.38): 'Conduplicatio is the repetition of one or more words for the purpose of Amplification or Appeal to Pity . The reiteration of the same word makes a deep impression upon the hearer a... The reiteration of wound upon the opposition - as if a weapon should repeatedly pierce the same wound upon the
part of the body.'

41.that: 'their sins are forgiven, knowing Christ, having conquered the evil one, knowing the Father, knowing Christ, being strong, having the word of God abiding within, and overcoming the evil one'. as the metaphors ${ }^{42}$ embedded in the text' (cf. Iser 1978:150; Van der Merwe 2015:5). For Iser (1978) almost everything in texts, such as:

physical images, material objects, attitudes or events described in the text are imaginatively experienced. The reading process then facilitates the passive fusion between the meaning of a text and the experience of the text in the mind of the readers. This entails a connection between the text and the readers: The readers themselves, ... in constituting the meaning, is also constituted. (p. 150)

The following images occur in the texts where the author refers to him 'writing these things' ( $\tau \alpha \tilde{\tau} \alpha$ है $\gamma \rho \alpha \psi \alpha)$. His reference to $\tau \alpha \tilde{\tau} \tau \alpha$ है $\gamma \rho \alpha \psi \alpha$ is to prepare the reader for these implied images created by the text in order to foster lived experiences of the divine to result in the realisation of the

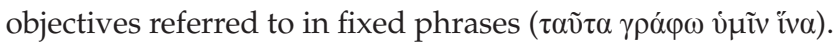

\section{Images from chapter 1 - Seen, heard, touched and fellowship}

The author refers in 1:1-3 repeatedly to the fact that they 'have heard, seen with their eyes and touched with their hands the Word of life', which refers in this context to Jesus Christ the Son of God. The readers, acquainted with the Gospel of John, had to give content to these indefinite verbs. For each reader, their lived experiences will be subjectively different depending on both the reader's knowledge of the Gospel and imagination. Which miracles are imagined, which discourses are abstracted? How real do they envisage Jesus? All this will create real and different lived experiences of Jesus. Even when they try to conceptualise 'fellowship', a mental experience of God can be imagined.

\section{Images from chapter 2 - The use of metaphors}

Already in chapter 1 the author introduces the family metaphor. ${ }^{43}$ He uses a coherent network of metaphors that

42.The American Heritage Dictionary of the English Language (Pickett 2000:1104) defines the word metaphor as a 'figure of speech in which a word or phrase that ordinarily designates one thing is used to designate another, thus making an implicit comparison' and 'one thing conceived as representing another, a symbol'. For the different kinds of metaphor, the dynamics of metaphor, ambiguities in
metaphor and the transformative power of metaphor, see Paprotte and Dirven 1985; Lakoff and Johnson 1992; Stern 2000; Aaron 2001; Punter 2007; Gibbs 2008 Loue 2008; Kovecses 2015

43.Influenced by Reinstorf and Van Aarde (2002:722), it can be noted that traditionally a metaphor was defined as 'an elliptical simile useful for stylistic, rhetorical, and didactic purposes, but which can be translated into a literal paraphrase without any loss of cognitive content' (cf. Johnson 1981:4). This explanation is based on two basic constituents: (1) a single word carried the focus and (2) the similarity caused the comparison. For many centuries, the notion occurred that meaning lay (the medaphorical transfer of 'giving a thing a name definition of a metaphor, cf. Johnson 1981:5) was understood to lie within the cadre of words. Consequently, a metaphor was understood to be the substitution of one word (used literally) with another word (used figuratively) based on the similarities that existed between the two words. Such a substitution was generally seen as a deviance from the literal or proper use of a word. As such the function of the metaphor was confined to providing rhetorical and stylistic ornamentation of a truth already (literally) known (Reinstorf \& Van Aarde 2002:722). The 20th century brought about a change in the understanding of a metaphor: 'the basic semantic unit is larger than the word' (Reinstorf \& Van Aarde 2002:722). This semantic change was reflected by Richards (1981:51) in his description of the metaphor. According to him: '... when we use a metaphor we have two thoughts of different things active together and supported by a single word, or phrase, whose meaning is a resultive together and supported by a single word, or phrase, whose meaning is a resultant of their interaction. This description caused Reinstorf and Van Aarde (2002:722; see also Van der Watt 2000:1-24) to distinguish the following factors: (1) Juxtaposed in a metaphor are not just words but thoughts (or worldviews); (2) the thoughts find expression not only through individual words, but phrases (or whole stories), and (3) the meaning of the metaphor is not the result of a litera word being substituted by a figurative word, but interaction; that is, two (often diverging) thoughts being juxtaposed. 
relate to first century family life ${ }^{44}$ (cf. Lassen 1997:103; Van der Merwe 2010:209; Van der Watt 1999:491) to explain certain vital concepts, the Christian identity and Christian conduct. The author uses this household metaphor to draw the reader into the text and to experience his teaching. He included mostly accepted and familiar conventions from everyday life to link them with how the readers lived in the community. $\mathrm{He}$ adapted to the idiom of his day by using generally accepted customs in family life (obedience, love, to know the truth) to express Jesus and God's relation and their relationship to the members of the community and what the Christian life comprises (cf. Van der Watt 1992:272-279).

The author pictured the Christian life of the readers as life in the familia Dei (Van der Watt 2000:157, 171-394; cf. Rusam 1993:105ff; Van der Merwe 2010:209). God is referred to as Father $(1: 2,3 ; 4: 14)$ and Jesus is the only Son of God (4:9; cf. $10,14)$. The believers are understood to be the children of God (3:1-2, 10; 5:2), born of God (2:29; also cf. 3:9, 10; 4:7; 5:1, $4 ; 18)$ and having the seed of God (3:10). In 2:12-14, he

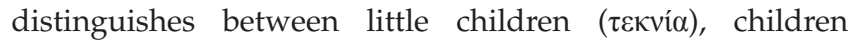

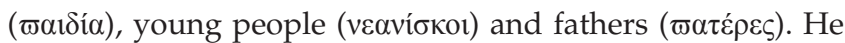
also addresses the readers in family style, such as 'beloved' (A $\gamma \alpha \varpi \eta \tau o$ i). Although only one reference to the 'Spirit of God' occurs (4:2f.), it is clear from 3:24 and 4:13 that the Sprit constitutes the presence of the Father.

\section{Images from chapter 5 - The ministry of Jesus}

In chapter 5, the author again uses water and blood as metaphors referring to the baptism and crucifixion of Jesus. ${ }^{45}$ In fact, he wants to incorporate Jesus' entire ministry to serve as a testimony from God that Jesus is the Son of God: 'Those who believe in the Son of God have the testimony of God in their hearts'. Also here, as in chapter 1 , the reader can imagine the entire ministry of Jesus. This again reflects on the unity that exists between God and his Son. The lived experience of the one constitutes a lived experience of the other.

\section{Dialectic of retention and pretention}

Waaijman (2002:744) also points out that when:

a text is descriptive, it arouses images in the imagination of the reader. These images emerge against the background of what the reader has already read and (during repetitions) against the background of what still lies ahead to be read. The text continues to disclose itself at every moment of reading. (Van der Merwe 2015:7)

This dialectic produces numerous 'lived experiences'. The disclosing of the text then happens against 'the combined background of memory and expectation' (Van der Merwe

44.See the three references for a more elaborated discussion on family life in antiquity See also Van der Merwe (2009).

45.See Painter (2002:302-309) for a thorough analysis of the interpretation and meaning of 'water and blood' referred to by the author in 5:6-8. It seems, according to him, as if there is no consensus amongst scholars with regard to the mording to him, as if there is no consensus anongst scholars with regard to the meaning and usage of these the mo interpret it as referring to the beginning (baptism) and ending (blood) of Jesus' ministry makes sense in the context of this essay. The most common view, according to Painter (2002:305), 'is that the water refers to the baptism of Jesus and blood to his death'.
2015:7; Waaijman 2002:744). The repetition of words, phrases and concepts strengthens this mechanism in the constitution of affects.

Take for instance eternal life: the author already introduced this concept in the prologue of 1 John. He refers to life ${ }^{46}$ three times in the prologue and relates it to Jesus Christ, the Son of the Father. In chapter 1, it is personified and refers to the identity of Jesus. At the end of 1 John, eternal life (5:11-13) is also attached to Jesus. In this context, the author uses 'eternal life' as a word event. Therefore, for the author to have faith in Jesus would lead to the experience of Jesus. In 1 John 2:6, he writes that "whoever says, "I abide in him," ought to walk just as he walked'.

The reference 'I am writing' complements all his references to his 'testimony', proclaiming, confessing and declaring. He uses it here to invite the reader to become involved in the experience of eternal life, which refers here to a new quality of life: living in the light, righteousness, love and truth. In the last reference to $\gamma \rho \alpha \dot{\varphi} \varphi \mathrm{v} v$ in 1 John 5:13 the author writes, 'I write these things to you who believe in the name of the Son of God, so that you may know that you have eternal life'. In this statement, the author's witness regarding Jesus culminates in his rebuking of the false teaching of his opponents regarding the identity of Jesus.

\section{Filling the gaps}

Literary texts represent potential effects that normally realise in the reading process (Iser 1978:ix). Gaps that occur in the reading (or listening) process, can only be filled by the reader - based on the reader's experiences and knowledge. For Iser, the reader must 'work it out for himself if he is to make the experience his own' (Iser 1978:46). Gaps develop when certain information is missing - this is what stimulates the reader into filling the blanks with projections (Iser 1978:168). This is exactly what happens in both chapters 1 and 5 . The vague references in these two chapters regarding the life of Jesus seem to be a deliberate mechanism used by the author for the reader to fill these gaps. This is evident from what was discussed in the previous section, 'The imaginative composition of images'. Here imagination plays a role, and imagination is experiential.

The neutral pronoun $\tau \alpha \tilde{\tau} \tau \alpha$ [these things, 1:4, 2:1, 2:26, 5:13] in the fixed phrase $\tau \alpha \tilde{\tau} \tau \alpha$ है $\gamma \rho \alpha \psi \alpha$ v $\mu \tilde{v} v$ iv $\alpha$ is a compound word in the sense the author uses it. In 1:4, he refers to the things he wrote about in the first three verses of chapter 1 and constitutes an openness to readers to fill the pronoun $\tau \alpha \tilde{v} \tau \alpha$ with their own imagination about Jesus' life. Their imagination is constituted by their knowledge of the Gospel of John. What the authors wrote about Jesus and God in these verses is filled with their knowledge about the Gospel. The fellowship created among them and their fellowship with the Father and Son created different lived experiences of the divine.

46.In $1: 1$, he refers to 'the word of life', and in $1: 2$ to both 'life' and 'eternal life'. 
Even in 2:1 it is connected with sin, 'I am writing these things to you so that you may not $\sin ^{\prime}$. The pronoun $\tau \alpha \tilde{v} \tau \alpha$ refers here to the previous pericope, the references 'to live in the light' and 'confession of sin'. Again the readers have to imagine or picture the content (regarding their experiences and knowledge) of sin and what it comprises to walk in the light, for God is light.

\section{Conclusion}

In this essay, we have taken cognisance of how the author has made intentional language choices when he wrote 1 John. His choices were functional and purposeful in order to achieve his primary and secondary objectives as spelt out.

This essay explored the possible strategy the author applied in his multiple references to 'writing' 1 John to influence his readers affectively and effectively. In 1 John he uses the


mechanism at strategic points to influence his readers. Through this phrase he attracted the readers' attention and established credibility about his understanding of and testimony about Jesus' identity. This facilitated his combatting of the deceivers' teaching about Jesus. He also successfully applied this phrase as a mechanism to create certain lived experiences in order that the readers would know that Jesus is the Son of God and therefore believe in him to achieve the various objectives he connected to this phrase.

When reading 1 John, at first glance, it may look like an informative text about Jesus' identity. However, it also has some transformative potential. It can work to inspire action in the world, to inspire the believer to experience imaginatively the divine in everyday life through living in the light and loving one another. The author wrote these things so that his readers could experience Jesus the Christ who is the Son of God and to experience through him something of God as Father, so that they may know that they have eternal life (5:13).

\section{Acknowledgement}

The author thanks Proff. Celia Kourie and Pieter de Villiers for their leadership roles in the discipline of Christian Spirituality in South Africa.

\section{Competing interests}

The author declares that he has no financial or personal relationships that may have inappropriately influenced him in writing this article.

\section{References}

Aaron, D.H., 2001, Biblical ambiguities: Metaphor, semantics and divine imagery, Brill, Leiden.

Akin, D.L., 2001, 1, 2, 3 John, Broadman \& Holman Publishers, Nashville, TN.

Aristotle, Rhetoric, Perseus, viewed 23 April 2018, from http://www.perseus.tufts. edu/hopper/text?doc=Perseus $\% 3$ Atext $\% 3 A 1999.01 .0060 \% 3 A$ book $\% 3 D 1 \% 3 A c h$ apter $\% 3 \mathrm{D} 1 \% 3$ Asection $\% 31$
Barker, M., 1996, The Risen Lord: The Jesus of history as the Christ of faith, T \& T Clark, Edinburgh.

Batluck, M., 2010, 'Religious experience in New Testament research', Currents in Biblical Research 9(3), 339-363. https://doi.org/10.1177/1476993X10383201

Bauckham, R., 1978, 'The sonship of the historical Jesus in Christology', Scottish Journal of Theology 31(3), 245-260. https://doi.org/10.1017/S0036930600035730

Bockmuehl, M.N.A., 1990, Revelation and mystery in ancient Judaism and Pauline Christianity (WUNNT 2.36), Mohr Siebeck, Tübingen.

Bruce, F.F., 1970, The epistles of John, Pickering \& Inglis Ltd, London.

Bultmann, R., 1973, The Johannine epistles: A commentary on the Johannine epistles, Fortress Press, Philadelphia, PA.

Cicero, Rhetorica ad Herennium, The Internet archive, viewed 15 April 2018, from https:// archive.org/stream/adcherenniumdera00capluoft/adcherenniumdera00capluoft_ djvu.txt

Danker, F.W. (ed.), 2000, Greek English lexicon of the New Testament and other early Christian literature, 3rd edn., BDAG, University of Chicago Press, Chicago, IL.

Davies, S.L., 1995, Jesus the healer, SCM, London.

DeConick, A.D., 2006, 'What is early Jewish and Christian Mysticism?', in A.D. DeConick (ed.), Paradise now: Essays on early Jewish and Christian mysticism, pp. 1-26, SBL, Atlanta, GA

Dunn, J.D.G., 1997, Jesus and the spirit: A study of the religious and charismatic experience of Jesus and the first Christians as reflected in the New Testament, William B. Eerdmans, Grand Rapids, MI.

Eskola, T., 2001, Messiah and the throne: Jewish Merkabah mysticism and early Christian exaltation discourse (WUNT, 2.142), Mohr Siebeck, Tübingen.

Fee, G.D., 1994, God's empowering presence: The holy spirit in the letters of Paul, Hendrickson, Peabody, MA.

Flannery, F., 2008, 'Introduction: Religious experience past and present', in F. Flannery, C. Shantz \& R. Werline (eds.), Experientia, Volume I: Inquiry into religious experience in early Judaism and early Christianity, pp. 1-10, SBL, Atlanta, GA.

Fletcher-Louis, C., 2008, 'Religious experience and the Apocalypses', in F. Flannery, C. Shantz \& R. Werline (eds.), Experientia, Volume I: Inquiry into religious experience in early Judaism and early Christianity, 125-144, SBL, Atlanta, GA.

Friberg, T., Friberg, B. \& Miller, N.F., 2000, Analytical lexicon of the Greek New Testament, Baker Books, Grand Rapids, MI.

Gibbs, R.W., 2008, The Cambridge handbook of metaphor and thought, Cambridge University Press, Cambridge.

Gunkel, H., 1888, Die Wirkungen des heiligen Geistes nach der populären Anschauung der apostolischen Zeit und nach der Lehre des Apostels Paulus, Van-denhoeck \& Ruprecht, Göttingen.
Rut

Haas, C., De Jonge, M. \& Swellengrebel, J.L., 1972, A translator's handbook on the letters of John, United Bible Society, London.

Haas, C., Jonge, M. de \& Swellengrebel, J.L., 1994, A handbook on the letters of John, United Bible Societies, New York.

Hiebert, D.E., 1988, 'An exposition of 1 John 1:1-4', Bibliotheca Sacra 145, 197-210.

Horn, F.W., 1992, Das Angeld des Geistes, Vandenhoeck \& Ruprecht, Göttingen.

Hurtado, L.W., 1988, One God, one Lord, Augsburg Fortress, London.

Hurtado, L.W., 2000, 'Religious experience and religious innovation in the New Testament', The Journal of Religion 80, 183-205. https://doi.org/10.1086/490606 Hurtado, L.W., 2003, Lord Jesus Christ, Eerdmans, Grand Rapids, MI.

Johnson, L.T., 1998, Religious experience in earliest Christianity: A missing dimension in New Testament studies, Augsburg Fortress, Minneapolis, MN.

Iser, W., 1978, The act of reading: A theory of aesthetic response, Johns Hopkins University Press, Baltimore.

Johnson, M., 1981, 'Metaphor in the philosophical tradition', in M. Johnson (ed.), Philosophical perspectives on metaphor, pp. 3-4, University of Minnesota Press, Minneapolis, MN, viewed 28 April, from https://books.google.co.za/books?id=Y $6 \mathrm{TzgsS} 035 \mathrm{kC} \&$ printsec=frontcover \&dq=Philosophical+perspectives+on+metap hor\&hl=en\&sa=X\&ved=0ahUKEwjlztnVsKXcAhUIBcAKHZB2CAMO6wEIKTAA\#v= onepage \&q=Philosophical\%20perspectives $\% 20$ on $\% 20$ metaphor $\& f=$ false

Jones, P.R., 2010, 'A presiding metaphor of first John', Pespectives in Religious Studies $37(2), 179-193$.

Kistemaker, S.J. \& Hendriksen, W., 2001, Exposition of James and the epistles of John Baker Book House, Grand Rapids, MI.

Klauck, H.-J., 1990, 'Zur rhetorischen analyse der Johannesbriefe', Zeitschrift für die Neutestamentliche Wissenschaft 81, 205-224.

Kövecses, Z., 2015, Where metaphors come from: Reconsidering context in metaphor, Oxford University Press, Oxford.

Kruse, C.G., 2000, The letters of John, Grand Rapids, MI.

Lakoff, G. \& Johnson, M., 1992, Metaphors we live by, The University of Chicago Press, London.

Lassen, E.M., 1997, 'The Roman family: Ideal and metaphor', in H. Moxnes (ed.), Constructing early Christian families: Family as social reality and metaphor, pp. 103-120, Routledge, London.

Law, R., 1909, The tests of life. A study of the first epistle of St John, T \& T Clark, Edinburgh.

Levinson, J.R., 2009, Filled with the spirit, William B. Eerdmans, Grand Rapids, MI. 
Lieu, J., 1997, The theology of the Johannine epistles, Cambridge University Press, Cambridge.

Loue, S., 2008, The transformative power of metaphor in therapy, Springer, New York.

Louw, J.P. \& Nida, E.A., 1996, Greek-English lexicon of the New Testament: Based on semantic domains, vol. I, United Bible Societies, New York.

Marshall, I.H., 1978, The epistles of John, William B. Eerdmans, Grand Rapids, MI.

McKnight, S., 1995, 'Who is Jesus? An introduction to Jesus studies', in M.J. Wilkin \& J.P. Moreland (eds.), Jesus under fire, pp. 51-72, William B. Eerdmans, Grand Rapids, MI.

Nordquist, R., 2017, Conduplicatio in rhetoric: Glossary of grammatical and rhetorical terms, viewed 15 April 2018, from https://www.thoughtco.com/whatis-conduplicatio-rhetoric-1689906

O'Collins, G., 1984, 'Luminous appearances of the risen Christ', CBQ 46, 247-254.

Painter, J., 2002, 1, 2, and 3 John, The Liturgical Press, Collegeville, PA.

Paprotté, W. \& Dirven, R., 1985, The ubiquity of metaphor: Metaphor in language and thought, John Benjamins Publishing Company, Amsterdam, MI.

Pickett, J.P. (ed.), 2000, American Heritage Dictionary of the English Language, Houghton Mifflin Company, Boston, MA.

Porter, S.E., Reed, J.T. \& O'Donnell, M.B., 2010, Fundamentals of New Testament Greek, William B. Eerdmans, Grand Rapids, MI.

Punter, D., 2007, Metaphor, Routledge, London.

Reinstorf, D. \& Van Aarde, A., 2002, 'Reflections on Jesus' parables as metaphorical stories past and present', HTS Theological Studies 58(2), 721-745. https://doi. org/10.4102/hts.v58i2.559

Richards, I.A., 1981, 'The philosophy of rhetoric', in M. Johnson (ed.), Philosophical perspectives on metaphor, pp. 48-62, University of Minnesota Press, Minneapolis, MN.

Rusam, D., 1993, Die Gemeinschaft der Kinder Gottes, Verlag W. Kohlhammer Stuttgart.

Schnackenburg, R., 1984, Die Johannesbriefe (HThK 13/3), Verlag Herder, Freiburg.

Smalley, S.S., 1989, 1, 2, 3 John, Word Biblical Commentary, vol. 51, Word Incorporated, Dallas.

Stern, J., 2000, Metaphor in context, The MIT Press, Cambridge.

Stott, J.R.W., 2009[1964], The letters of John, TNTC, Intervarsity Press, Nottingham.

Stowers, S.K., 1986, Letter writing in Greco-Roman antiquity, Westminster Press, Philadelphia, PA

Strecker, G., 1996, The Johannine letters (A commentary on 1, 2, and 3 John), Fortress Press, Minneapolis, MN.

Thomas, J.C., 2004, The Pentecostal Commentary on 1 John, 2 John, 3 John, The Pilgrim Press, Cleveland, $\mathrm{OH}$

Thomas, J.C., 2006, The pentecostal commentary on 1 John, 2 John, 3 John, The Pilgrim Press, Cleveland.
Thompson, M.M., 1992, 1-3 John, InterVarsity, Downers Grove, IL.

Turner, M., 1996, The holy spirit and spiritual gifts: Then and now, Carlisle, Paternoster.

Van der Merwe, D.G., 2005, 'Salvation in the Johannine Epistles', in J.G. Van der Watt (ed.), Salvation in the New Testament: Perspectives on soteriology, pp. 437-464, Brill, Leiden.

Van der Merwe, D.G., 2006, 'Having fellowship with God according to 1 John: Dealing with the intermediation and environment through which and in which it is constituted', Acta Theologica Supplementum 8, 165-192.

Van der Merwe, D.G., 2007, 'The construction of phenomena that caused a schism in the Johannine community at the end of the first century $\mathrm{CE}^{\prime}$, Hervormde Teologiese Studies 63, 1149-1169. https://doi.org/10.4102/hts.v63i3.234

Van der Merwe, D.G., 2009, 'Family Metaphorics: A rhetorical tool in the Epistle of 1 John', Acta Patristica et Byzantina 20(1), 89-108. https://doi.org/10.1080/10226 486.2009.11879098

Van der Merwe, D.G., 2010, 'Domestic architecture: Culture, fictive kinship and identity in the Gospel of John', Acta Patristica et Byzantina 21(2), 207-226. https://doi.org/10.1080/10226486.2010.11879127

Van der Merwe, D.G., 2013, 'Early Christian spirituality according to the First Epistle of John: The identification of different lived experiences', HTS Theological Studies 69 (1), 1-9. https://doi.org/10.4102/hts.v69i1.1286

Van der Merwe, D.G., 2015, '1 John: "Effects" in biblical texts that constitute "lived experiences" in the contemplative reading of those texts', In die Skriflig 49(2), 1-9. https://doi.org/10.4102/ids.v49i2.1930

Van der Watt, J.G., 1992, 'Interpreting imagery in John's Gospel: John 10 and 15 as case studies', in J. Barkhuizen et al. (eds.), Hupomnema: Feesbundel opgedra aan J.P. Louw, pp. 272-282, Universiteit van Pretoria Press, Pretoria.

Van der Watt, J.G., 1999, 'Ethics in First John: A literary and socio-scientific perspective', Catholic Biblical Quarterly 61, 491-511.

Van der Watt, J.G., 2000, Family of the King: Dynamics of metaphor in the Gospel according to John, Brill, Leiden.

Waaijman, K., 2002, Spirituality: Forms, foundations, methods, transl. J. Vriend, Peeters, Dudley.

Wallace, D.B., 1997, Greek grammar beyond the basics. An exegetical syntax of the New Testament, Zondervan, Grand Rapids, MI.

Wallace, D.B., 2009, Basics of New Testament Syntax, Zondervan, Grand Rapids, MI.

Watson, D.F., 1989, '1 John 2.12-14 as Distributio, Conduplicatio, and Expolitio: A rhetorical understanding', Journal for the Study of the New Testament 35, 97-110. https://doi.org/10.1177/0142064X8901103507

Westcott, B.F., 1982[1886], The epistles of St John (Johannine studies since Westcott's day by F.F. Bruce), William B. Eerdmans, Grand Rapids, MI.

Westcott, B.F., 2004[1908], The Gospel according to St. John: The Greek text with introduction and notes, Wipf \& Stock Publishers, Eugene, viewed 17 April 2018 from https://books.google.co.za/books?id=9vxKAwAAQBAJ\&printsec=frontcove $\& d q=$ Westcott,+ Gospel+of+John\&hl=en \&sa $=X \& v e d=0$ ahUKEwiXs7LS7cHaAhVDS BOKHYLXCmgQ6wEIJzAA\#v=onepage \&q=Westcott $\% 2 \mathrm{C} \% 20$ Gospel $\% 20$ of $\% 20$ John\& $\mathrm{f}=$ false 